\title{
Analysis of the Influence of Corn Plantation Potential on Farmer Income in Tang Village, Kecamatan Bokat, Buol District \\ (A Case Study of Corn Farmers in Tang Village, Bokat District, Buol Regency)
}

\author{
Ramlawati ${ }^{*}$, Hilmi ${ }^{1}$ \\ ${ }^{1}$ Deparment of Development Planning, STIE Mujahidin Tolitoli, Sulawesi Center, Indonesia
}

\begin{abstract}
This study aims to determine and analyze the potential effect of corn plantations on farmer income in Tang Village, Bokat District, Buol Regency. This study uses a quantitative research design. The data source is in the form of primary data, namely data obtained through interviews, and documentation related to this research. The data analysis technique used is multiple linear regression. Based on the results of the research and discussion, it can be concluded that the variables of land area, production costs, labor, and selling prices simultaneously have a positive and significant effect on the income of corn farmers in Tang Village, Bokat District, Buol Regency. The results of the research partially show that the selling price variable has a positive and significant effect on the income of corn farmers in Tang Village, Bokat District, Buol Regency, while the variables of land area, production costs, and labor have a positive but not significant effect on the income of corn farmers in Tang Village, Bokat District. Buol Regency.
\end{abstract}

Keywords: Land Area, Production Costs, Labor, Selling Price, Corn Farmer's Income

*Corresponding Author:

E-mail: ramlawati@stiemujahidin.ac.id (Ramlawati)

Deparment of Development Planning, STIE Mujahidin Tolitoli, Sulawesi Center, Indonesia

\section{INTRODUCTION}

Indonesia is an agricultural country, meaning that agriculture plays an important role in the entire national economy. This is aimed at the large number of people or workers who live or work in the agricultural sector or from national products derived from agriculture.

The agricultural sector is one of the sectors that is relied on to support economic growth both at present and in the future. Growth in the agricultural sector needs special and serious attention from various parties because growth in this sector is expected to guarantee national food security.

Farming net income is farm income minus the amount of farm expenses. This net income is the reward and effort of the farmer and his family in managing the farm.

One of the secondary crops that is used as food is the corn plant. In Indonesia, maize plays a second role after rice. As a food ingredient, corn has no less nutritional value than rice. Apart from being used for human food, corn can also be used for animal feed, industrial raw materials, beverages, syrup, paper, oil, paint and others.

Central Sulawesi Province is one of the major maize producers in Indonesia. Corn production in Central Sulawesi is supported by several districts. One of these areas is Buol Regency.

Tang Village, Bokat District, is an area in Buol Regency that produces and 
cultivates maize to meet community needs. This plant is a type of plant whose results are used to increase people's income. The land area owned by Tang Village for corn farming is +/- $300 \mathrm{Ha}$ which is managed by 8 farmer groups, each group consisting of 15-30 people.

In general, the potential income of farmers from a farm is very dependent on the amount of production costs. Especially for land supply, production costs, labor, and selling price, all of which are very influential on the size of the income and the income that farmers / respondents get from their farming products.

Based on the description above, the researcher needs to conduct a research entitled "Analysis of the Potential Influence of Corn Plantation on Farmers' Income in Tang Village, Bokat District, Buol Regency".

Formulation of the problem

Based on the title and description on the background, the formulation of the problems to be examined in the research is as follows:

1. Does the land area affect the income of corn farmers in Tang Village, Bokat District, Buol Regency?

2. Does the production cost affect the income of corn farmers in Tang Village, Bokat District, Buol Regency?

3. Does labor affect the income of corn farmers in Tang Village, Bokat District, Buol Regency?

4. Does the selling price affect the income of corn farmers in Tang Village, Bokat District, Buol Regency?

5. Do land area, production costs, labor and selling price affect the income of corn farmers in Tang Village, Bokat District, Buol Regency?

\subsection{Literature Review, Framework and Hypothesis}

\subsubsection{Literature Review}

The definition of potential is an ability, ability, strength or power that has the possibility to be developed into a larger form (Majdi, 2007).

(Winardi, 2007) states that income is the result of money or other material obtained from the use of capital or wealth.

Clarifying the notion of income, the understanding of income from experts is stated: (Simangunsong, 2004) argues that: "Income is the increase in company assets or cash, receivables, other assets that come from the sale of goods or services which results in increased capital". Agricultural science according to (Soekartawi, 1995) is the study of how a person allocates existing resources effectively and efficiently for the purpose of obtaining high profits at a certain time.

According to (Sukirno, 2008), in general, production factors can be explained as follows: Production factors are things provided by nature or created by humans that can be used to produce goods or services. These production factors include:

a) Soil

Land as one of the factors of production usually consists of economic or material goods provided by nature without human assistance. This term does not only cover the surface of the land and water, but everything that is contained therein. So, the land here includes all natural resources in its state. natural, such as mineral sources, wild animals, wood, fish and others.

b) Capital

According to (Mubyarto, 1973) states the definition of capital, namely: Capital is money or goods on a large scale with other production factors (land and labor) producing new goods. Although capital is always expressed in terms of 
Journal of Sustainable Develpment Science

Vol. 3, No. 1, June 2021, pp. 35-44

e-ISSN: 2715-9140 | p-ISSN: 2722-919X

money, there is also the creation of capital without the use of money.

c) Labor

Labor is a number of residents who can be used in the production process, but including the skills they have which is an element of education that helps society by providing a combination of physical and intelligence energy for a production process.

d) Skills and Skills

Economic development according to Schumpeter (1934) was mainly created with the initiative of an innovative producer group or some experts call it entrepreneurship.

\section{Factors Affecting Corn Revenue}

a. Land area

Land as one of the production factors is a factory of agricultural products, namely the place where production runs and where the output comes from. According to (Daniel, 2002) land is a key factor in agricultural business. Without land, farming cannot be done. The definition of land here is not just the real form of the land, but the meaning in which farming is carried out.

b. Production cost

1) Fertilizer

Fertilizer is a food substance or substance that is given or added to plants with the intention of making the plant grow. The main benefit of fertilizers related to the physical properties of the soil is to improve the soil structure from solid to loose.

2) Pesticide

Pesticides are chemical substances, other substances, microorganisms and viruses that are used to kill pests and diseases. On the one hand, pesticides can benefit farming businesses, but on the other hand, pesticides can harm farmers.
According to (Sujono \& Sudarmadi, 1989) which states that efforts to develop and increase agricultural production, especially maize, are carried out through an intensification program with the use of superior varieties, input of fertilizers and pesticides.

c. Labor

According to (Mubyarto, 1989) labor is a very important factor in production, because labor is a driving factor for other input factors, without skills and knowledge as well as the influence of age and human resources that are still low, the labor factor is meaningless..

d. Selling price

In the theory of supply states the willingness and willingness of sellers as individuals and markets to sell goods to consumers. The price of the goods to be determined by the supplier takes into account the costs used to create the goods in question.

\subsubsection{Framework of Mind}

The initial assumption in this study is that maize income in Tang Village, Bokat District, Buol Regency is influenced by the variables of Land Area (X1), Production Costs (X2), Total Labor (X3), and Corn Selling Price (X4).

Land area has a very strong relationship with maize income. The area planted affects the number of plants planted, which in turn can affect the amount of maize production. The more land is planted, the more income the farmers get. On the other hand, fertilizer is a food substance that is needed by plants to add nutrients to the soil in order to increase farm income. Meanwhile, the price of seeds and the price of pesticides used in farming, corn are calculated as production costs apart from the use of fertilizers. So that the number of production inputs used 
Journal of Sustainable Develpment Science

Vol. 3, No. 1, June 2021, pp. 35-44

e-ISSN: 2715-9140 | p-ISSN: 2722-919X

can affect the ups and downs of corn farming income.

The number of effective workers can encourage success in farming, so it is a very important factor in achieving success. The labor used generally comes from within the family coupled with labor from outside the family. In general, the use of labor in corn farming activities includes land processing, planting, plant maintenance and harvesting. Meanwhile, the output price variable (corn) has a major effect on maize farm income, which states that the amount of income is mainly determined by the output price which has a positive effect on increasing income.

To facilitate research activities to be carried out and to clarify thoughts, the following is a picture of the framework of "Analysis of Potential Influence of Corn Plantation on Farmers' Income in Tang Village, Bokat District, Buol Regency"

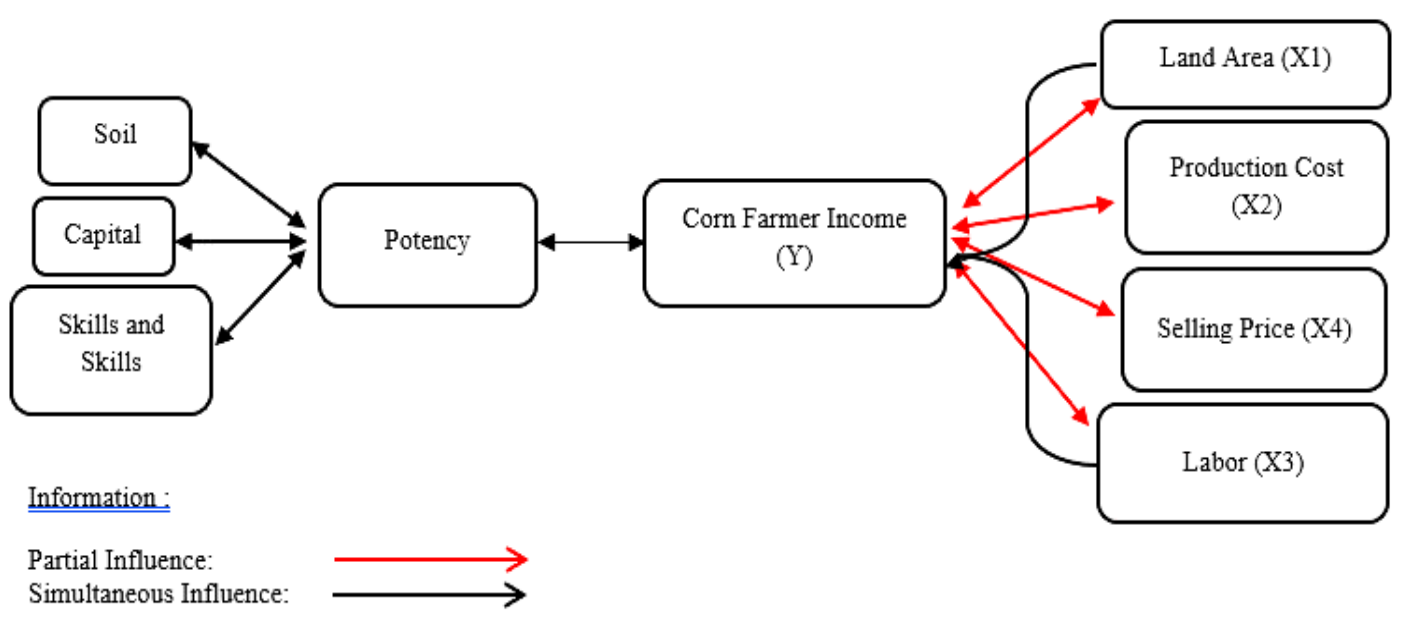

Fig. 1 Research Framework

\subsubsection{Research Hypothesis}

Based on the explanation and conceptual framework for this research, the following hypotheses can be formulated:

1. It is assumed that the land area has a positive and significant effect on the income of corn farmers in Tang Village, Bokat District, Buol Regency.

2. It is assumed that the production cost has a positive and significant effect on the income of corn farmers in Tang Village, Bokat District, Buol Regency

3. It is assumed that labor has a positive and significant effect on the income of corn farmers in Tang Village, Bokat District, Buol Regency

4. It is assumed that the selling price has a positive and significant effect on the income of corn farmers in Tang Village, Bokat District, Buol Regency.

5. It is assumed that land area, production costs, labor and selling 
Journal of Sustainable Develpment Science

Vol. 3, No. 1, June 2021, pp. 35-44

e-ISSN: 2715-9140 | p-ISSN: 2722-919X

price have a positive and significant effect on the income of corn farmers in Tang Village, Bokat District, Buol Regency.

\section{METHODS}

This type of research is a survey research type. This research is located in Tang Village, Bokat District, Buol Regency, on corn farmers, and is located on Jl. Trans Sulawesi. This study was planned for 3 months. Starting from June to August 2020.The method or method of data collection carried out in this study is interview, observation, documentation, and questionnaires. The types of data used in this research are quantitative data and qualitative data. Sources of data used in this study are primary data and secondary data.

The data analysis method used is multiple linear regression analysis. Data analysis was carried out through the classical assumption test stage consisting of multicollinearity test, heteroscedasticity test and normality test as well as hypothesis testing using the $t$ test, f test, and coefficient of determination.

\section{RESULTS AND DISCUSSION}

3.1. Classical Assumption Test Results 3.1.1. Multicollinearity Test Results

Table I

Multicollinearity Test Results

Based on Table I, it can be concluded that between the independent variables there is no correlation or multicolonierity symptoms do not occur. This can be seen from the results of the calculation of the Tolerance value of more than 0.10 and the Variance Inflation Factor (VIF) value of less than 10, this means that there is no multicolinearity between the independent variables.

\subsubsection{Result Heteroscedasticity Test}

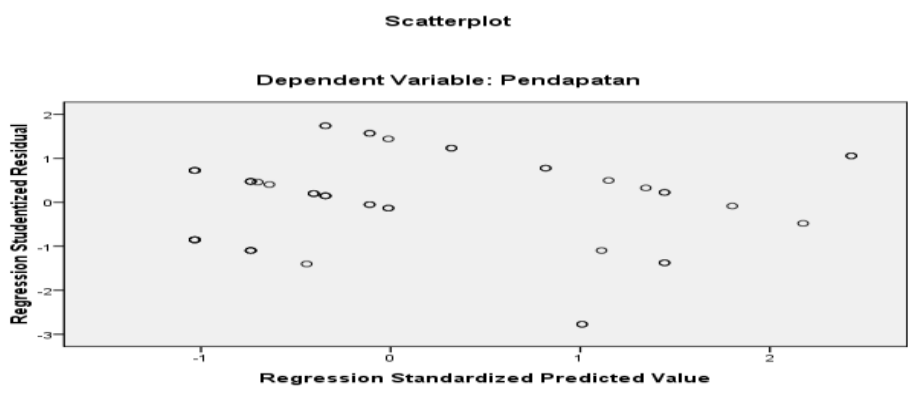

Source: SPSS 16 output based on research data, 2020

Fig. 2 Heteroscedasticity Test Results

Journal Homepage:

http://ejournal.undwi.ac.id/index.php/jsds
Copyright (C) 2021 Dwijendra University. All right reserved. 
Based on the picture above, it can be seen that the dots are still spreading above and below the number 0 on the $\mathrm{Y}$ axis.
This means that there is no heteroscedasticity in the regression model and the model is suitable for use.

\subsubsection{Result Normality Test}

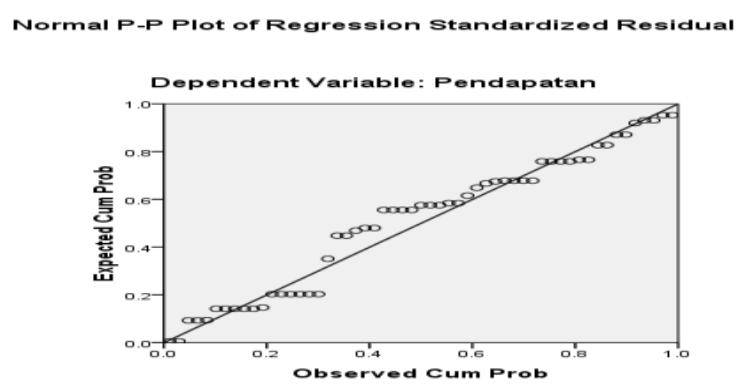

Source: SPSS 16 output based on research data, 2020

Fig. 3 Normality Test Results

Based on the normal plot graph display, it can be seen that the data still follows and spreads around the diagonal line.
So it can be concluded that the regression model has met the normality assumption.

\subsection{Results of Multiple Linear Regression Analysis}

Table II

Multiple Linear Regression Test Results

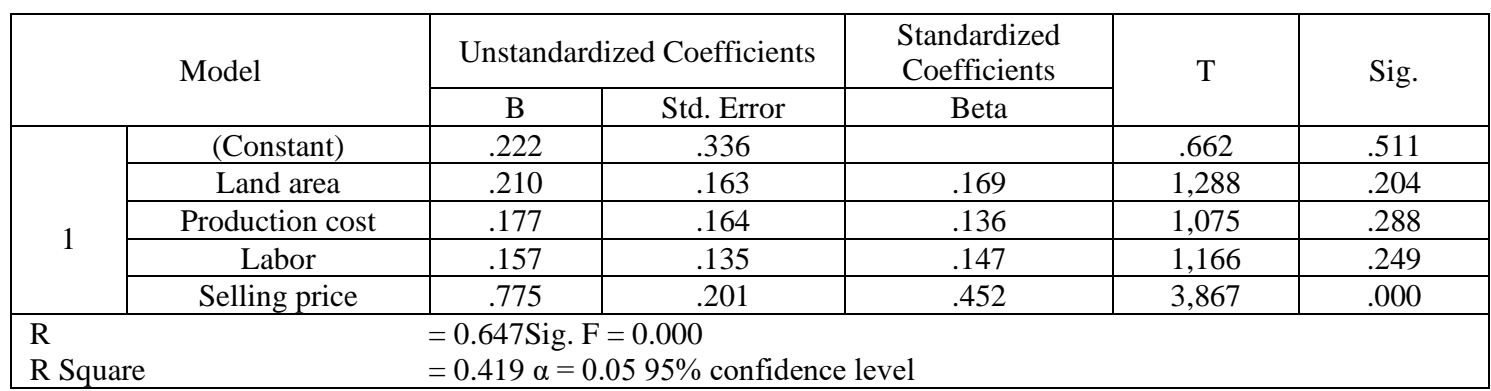

Based on Table II above, it can be written in the form of multiple linear regression equations.

For more details, the form of the equation can be seen as follows:

$$
\begin{gathered}
\operatorname{Ln} \mathrm{Y}=\mathrm{Ln} \beta \mathrm{o}+\beta 1 \ln \mathrm{X} 1+\beta 2 \ln \mathrm{X} 2+ \\
\beta 3 \ln \mathrm{X} 3+\beta 4 \ln \mathrm{X} 4+\mu \\
\mathrm{Y}=0.222+0.210 \mathrm{X} 1+0.177 \mathrm{X} 2+0.157 \\
\mathrm{X} 3+0.775 \mathrm{X} 4+\mathrm{e}
\end{gathered}
$$

The results of the regression equation can be explained as follows:

a. The constant value $b 0=0.222$ shows the amount of income of maize farmers when land area (X1),

\section{Journal Homepage:}

http://ejournal.undwi.ac.id/index.php/jsds production costs (X2), labor (X3), selling price (X4) are equal to zero.

b. The independent variable of land area (X1) has a regression coefficient (b1) of 0.210 indicating that the effect of the respondent's land area is positive $(+)$. This means that if the respondent's land area increases by 1 hectare, it will cause an increase in income of 0.210 with the assumption that production costs (X2), labor (X3), and selling price (X4) are considered constant.

c. The production cost-free variable (X2) has a regression coefficient (b2) of 0.177 indicating a positive effect $(+)$ of

Copyright @ 2021 Dwijendra University. All right reserved. 
fertilizer. This means that if the use of fertilizers is good, it will cause an increase in the income of corn farmers of 0.177 with the assumption that land area (X1), labor (X3), and selling price (X4) are considered constant.

d. The labor-free variable (X3) has a regression coefficient (b3) of 0.157 indicating that the labor effect is positive (+). This means that if the workforce increases by 1 person, it will cause an increase in corn farmer income of 0.157 with the assumption that land area $(\mathrm{X} 1)$, production costs (X2), and selling price (X4) are considered constant.

e. The independent variable selling price (X4) has a regression coefficient (b4) of 0.775 indicating the effect of the respondent's selling price which is positive (+). This means that if the respondent's selling price increases by 1 , it will cause an increase in income of 0.775 with the assumption that land area (X1), production costs (X2), labor (X3), are considered constant.

\subsection{Hypothesis test}

\subsubsection{Test (partial test)}

The $\mathrm{t}$ test is used to determine whether each independent variable partially has a significant effect on the dependent variable. If the significance probability value is less than 0.05 ( $\mathrm{Sig}$ $<0.05)$ then the independent variable partially affects the dependent variable. Conversely, if the significance probability value is more than 0.05 (Sig> 0.05), the independent variable has no effect on the independent variable. The $\mathrm{t}$ test can be seen in the table below:

Table III

T statistical test results (partial)

\begin{tabular}{|c|c|c|c|c|c|c|}
\hline & \multirow[t]{2}{*}{ Model } & \multicolumn{2}{|c|}{ Unstandardized Coefficients } & \multirow{2}{*}{$\begin{array}{c}\begin{array}{c}\text { Standardized } \\
\text { Coefficients }\end{array} \\
\text { Beta } \\
\end{array}$} & \multirow[t]{2}{*}{$\mathrm{T}$} & \multirow[t]{2}{*}{ Sig. } \\
\hline & & $\mathrm{B}$ & Std. Error & & & \\
\hline \multirow{5}{*}{1} & (Constant) & .222 & .336 & & .662 & .511 \\
\hline & Land area & .210 & .163 & .169 & 1,288 & .204 \\
\hline & Production cost & .177 & .164 & .136 & 1,075 & .288 \\
\hline & Labor & .157 & .135 & .147 & 1,166 & .249 \\
\hline & Selling price & .775 & .201 & .452 & 3,867 & .000 \\
\hline
\end{tabular}

Source: SPSS 16 output based on research data, 2020

Based on the table above it can be interpreted that the $t$ test results of the independent variables are as follows:

1. The variable of land area (X1) has a significant value of 0.204 , this value indicates that the value is not significant, because it is greater than the level of significance $(\alpha=0.05)$. So, the hypothesis states that land area has a significant effect on the income of corn farmers in Tang Village, Bokat District, Buol Regency. The first hypothesis is rejected.

2. The production cost variable (X2) has a significant value of 0.288 , this value indicates that the value is not significant, because it is greater than the level of significance $(\alpha=0.05)$. So, the hypothesis which states that production costs have a significant effect on the income of corn farmers in Tang Village, Bokat District, Buol Regency. The second hypothesis is rejected.

3. The labor variable (X3) has a significant value of 0.249 , this value indicates that the value is not significant, because it is greater than the level of significance $(\alpha=0.05)$. So, the hypothesis states that labor has a 
significant effect on the income of corn farmers in Tang Village, Bokat District, Buol Regency. The third hypothesis is rejected.

4. The selling price variable (X4) has a significant value of 0.000 , this value indicates that the significant value is smaller than the level of significance $(\alpha=0.05)$. So, the hypothesis states that the selling price has a significant effect on the income of corn farmers in Tang Village, Bokat District, Buol Regency. The fourth hypothesis is accepted.
Based on the results of the ANOVA test (Analysis of Varian) or the F test, it was obtained that the Fcount value was 9,003> Ftable of 2.07 and the significance level was smaller than the level of distrust $(0,000<0.005)$. These results mean that land area (X1), production costs (X2), labor (X3) and selling price (X4) simultaneously have a significant effect on the income of corn farmers in Tang Village, Bokat District, Buol Regency (Y), so the fifth hypothesis submitted can be accepted. The results of the $\mathrm{F}$ test can be seen in the table below:

\subsubsection{Simultaneous Test $(F)$}

Table IV

Statistical Test Results F ANOVAa

\begin{tabular}{|l|c|c|c|c|c|}
\hline \multicolumn{1}{|c|}{ Model } & Sum of Squares & Df & Mean Square & F & Sig. \\
\hline 1 Regression & 15,301 & 4 & 3,825 & 9,003 & $.000 \mathrm{a}$ \\
& 21,245 & 50 & .425 & & \\
Residual & 36,545 & 54 & & & \\
Total & & & & \\
\hline
\end{tabular}

Source: SPSS 16 output based on research data, 2020

\subsubsection{Determination Coefficient Test}

Table V

Statistical Test Results F

Model Summaryb

\begin{tabular}{|c|c|c|c|c|c|}
\hline Model & $\mathrm{R}$ & $\mathrm{R}$ Square & Adjusted R Square & $\begin{array}{c}\text { Std. Error of the } \\
\text { Estimate }\end{array}$ & Durbin-Watson \\
\hline 1 & $.647 \mathrm{a}$ & .419 & .372 & .652 & 2,103 \\
\hline
\end{tabular}

The table above shows the value of the coefficient of determination (R Square) of 0.419 which means that the variations in the variable area of land, production costs, labor and selling price can explain the effect on the income of corn farmers in Tang Village, Bokat District, Buol Regency, which is $41.9 \%$, whereas the remaining $58.1 \%$ is explained by other variables not included in the calculation of this regression model.

Based on the results above, the writer can explain the following:

1. land area has a positive but insignificant effect on maize income.
This means that if the land area increases by 1 ha, it will affect income but the effect is not very real or strong. So that land area is not the main determinant (determinant) of the amount of production and income earned by corn farmers. Because maize farmers with the same land area do not necessarily have the same production, this is due to damage to the maize plant caused by wild animals, pests, and how to manage corn plants that depend on the owner, so land area cannot affect the income of corn 
farmers in the village Tang, Bokat District, Buol Regency.

2. Production costs have a positive but insignificant effect on the income of maize farmers. This means that if the production cost increases by one unit, it will affect the farmer's income by one unit, but the effect is not very real or strong. Production costs consist of fertilizer costs and pesticide costs. The application of fertilizers to plants can maintain the nutritional content of plants in the soil and improve or provide plant content that is lacking or even unavailable in the soil to support plant growth. So the use of suitable fertilizers can provide good maize productivity and can increase farmers' income. decreased

3. Labor has a positive but not significant effect on the income of maize farmers. This means that if the workforce increases by one unit, it will affect the income of farmers, but the effect is not very real or has an impact. The direction of the relationship between labor and income is unidirectional, where an increase or decrease in labor will result in an increase and decrease in maize income in Tang Village, Bokat District, Buol Regency. The labor used by maize farmers in Tang Village has a positive effect on maize income, but not significant, this is due

\section{CONCLUSIONS}

\subsection{Conclusion}

Based on the results of the data analysis carried out and the discussion that has been stated, the following conclusions are obtained:

1. The variable of land area does not have a significant effect on the income of maize farmers because it is to a lack of human resources because the quality of human resources is still of low quality.

4. The selling price has a positive and significant effect on the income of corn farmers, meaning that if the selling price increases by one unit it will affect the income by one unit and the effect is very strong. The direction of the relationship between the selling price and income is unidirectional, where an increase or decrease in the amount of the selling price will result in an increase and decrease in maize income in Tang Village, Bokat District, Buol Regency.

5. Based on the results of testing and analysis carried out in this study, it proves that the independent variables simultaneously have a positive and significant effect on the dependent variable. Based on the multiple linear regression recapitulation table, it can be seen that the effect of the determination test results is 0.419 . This value means that all the dimensions of the independent variables have a simultaneous or joint contribution of $41.9 \%$ to the dependent variable, namely the income of corn farmers. While the rest $(100 \%-41.9 \%=$ $58.1 \%$ ) is influenced by other variables that are not researched

also caused by inadequate management of land area, such as uneven land use which is partly used for rica, banana and clove crops.

2. The variable of production costs, in this case fertilizers and pesticides, have a positive but insignificant effect on the income of corn farming, because the use of fertilizers must be in accordance with the recommended 
dosage. If it exceeds it can cause the death of the plant and the continuous application of fertilizers can have a bad impact on soil conditions. The soil hardens quickly, less able to store water.

3. The labor variable has a positive but insignificant effect on the income of farmers because the more labor used will reduce the income to provide wages, the labor used in this case is daily workers and only at harvest time. This is because there are also many family members who help cultivate agricultural land.

4. The selling price variable has a positive and significant effect on farmers' income where an increase or decrease in the amount of the selling price will result in an increase and decrease in maize income in Tang Village, Bokat District, Buol Regency.

5. Based on the results of testing and analysis carried out in this study, it is evident that land area, production costs, labor and selling prices simultaneously have a positive and significant effect on the income of corn farmers in Tang Village, Bokat District, Buol Regency.

\subsection{Suggestions}

Based on the results of the research and the conclusions that the researcher has described, the suggestions that can be recommended are:

1. To increase the income of corn farmers, it is hoped that the relevant parties will provide assistance in the form of fertilizers and pesticides in a timely manner to farmers because fertilizers and pesticides play an important role in increasing the income of corn farmers.
2. To increase income for corn farmers, the government or the private sector must direct the farmers in terms of marketing the yields obtained and how to use technology in the marketing sector both in quality and quantity. So that the income earned by corn farmers has increased.

3. For future researchers, it is hoped that they will be able to develop the research that I have done to see other factors that affect the income level of corn farmers.

\section{REFERENCES}

Dumairy. (1999). Mathematics Applied To Business and Economics. IKAPI.

Daniel, M. (2002). Introduction to Agricultural Economics. PT. Buni Aksara.

Majdi, U. Y. E. (2007). Quranic Quotient: Menggali dan melejitkan potensi diri melalui Al-Quran (1st ed.). QultumMedia.

Mubyarto. (1973). Introduction to Agricultural Economics. LP3ES.

Mubyarto. (1989). Introduction to Agricultural Economics (3rd ed.). LP3ES.

Simangunsong, B. C. H. (2004). The Economic Performance of Indonesia's Forest Sector in the Period 1980-2002. Briefing Paper, 4, 6. https://scholar.google.com/scholar?clus ter $=698420967$ 0249727050\&hl=en\&oi=scholarr

Soekartawi. (1995). Farming Analysis. University of Indonesia Press.

Sujono, S., \& Sudarmadi. (1989). Pest and Disease Observation Techniques. Gadjah Mada University Press.

Sukirno, S. (2008). Introduction to Microeconomic Theory. PT. Raja Grafindo Persada.

Winardi. (2007). Performance Management. PT. Raja Grafindo Persada. 
Journal of Sustainable Develpment Science

Vol. 3, No. 1, June 2021, pp. 35-44

e-ISSN: 2715-9140 | p-ISSN: 2722-919X 